\title{
ピロティ構造内部に設置された 小規模構造に作用する津波波力特性
}

\author{
本田 隆英 1 -小俣 哲平 1 -織田 幸伸 1 - 伊藤 一教 2 \\ 1 正会員 大成建設（株）技術センター（†245-0051 神奈川県戸塚区名瀬町 344-1） \\ E-mail: hndtkh01@pub.taisei.co.jp \\ 2 フェロー会員 大成建設（株）技術センター（†245-0051 神奈川県戸塚区名瀬町 344-1）
}

\begin{abstract}
ピロティ構造は，津波に対して有効な構造形式であるが，エレベーターホールなどの 1 階小規 模構造物に働く津波外力の評価手法は確立されておらず，既存の指針を準用して算出すると過 小評価となる実験報告もある。そこで，この様な小規模構造物に働く津波波力特性の解明と， 波力評価手法の提案を目的とし，平面水槽を用いた津波波力実験を実施した。実験結果から， 津波波形によらず，直立壁の場合と同様に入射津波のフルード数と浸水深時系列を用いて波力 の経時評価が可能であることが示された. また，1階部材が後退し，衝突した津波の流体運動が 天井によって拘束される場合の津波波力は，入射津波の運動量を用いて推定可能であることが 示された.
\end{abstract}

Key Words : tsunami force, piloti-type structure, hydraulic physical model test, water depth amplification coefficient, momentum theorem

\section{1. はじめに}

2011年に発生した東北地方太平洋沖地震津波による被 害を受け，陸上構造物に対して津波に強い構造が求めら れている. 津波波圧は構造物の下層に大きく作用するた め, 津波に強い構造形式に, 1階に壁の無いピロティ構造 が挙げられる．ピロティ構造壁面に作用寸る津波外力の 算定方法は, ガイドライン1), 2)に示されている. しかし, ピロティ構造物の1階部分には耐震性確保のための柱や, エレベーターホールなどの小規模構造物が存在するが, ガイドライン1), 2)ではこれらの各部材に作用する津波外 力は明確には示されていない.

ピロティ構造および開口部を有する構造に対する津 波波力については，これまでに実験・解析の両面から研 究が進められてきた (例えば3) 6) 。最近では, 岩田ら7 は津波避難ビルを対象に, 低層階の柱の形状およひ配置 の違いによる津波波力特性を，水理模型実験により検討 している. また, 岩前ら ${ }^{8}$ は開口を有する建築物を対象 とした津波実験および解析を実施し, フルード数1.4以下 の津波条件では，建築物に働く最大波力は衝撃波力より 持続波力が支配的であるケースが多く，現行算定式は安 全側の評価を与えることを報告している.

著者ら9ははこれまで, 二次元水路を用いてピロティ構
造を対象とした津波実験を実施し，エレベーターホール などの1階部分小規模構造物や1階天井などに働く津波波 力を既存の指針を準用して算出すると過小評価となる場 合があり，また，来襲した津波が1階の小規模構造物壁面 に衝突して打ち上がると天井板に大きな津波波力が作用 することを報告した，さらに，著者ら ${ }^{10)}$ (以下，前報と 呼ぶ）は二次元水路の側壁の影響を受けない平面水槽を 用いてピロティ構造の津波実験を実施し, 津波波力特性 は水位上昇が緩やかな非衝撃津波と水位上昇が急な衝撃 津波で大きく異なることを示した. ここでは前報の実験 結果を再整理し, 小規模構造物に作用寸る津波波力特性 の解明と, 波力評価式の構築を目的とする.

\section{2. 実験方法}

\section{(1) 実験装置および実験模型}

水理模型実験には平面水槽（長さ $35.5 \mathrm{~m}$, 幅 $17.0 \mathrm{~m}$, 高さ $1.6 \mathrm{~m}$ ）を使用した. 津波の造波には，写真-1に示 す平面水槽内に設置したチャンバー式津波造波装置を用 いた. 平面水槽では, 1 基のチャンバー (貯水容量 $80 \mathrm{~m}^{3}$, 空気供給バルブ 8 台）を直線状に 8 基配置し，造波装置 幅を $12.0 \mathrm{~m}$ として, 波高および波形が異なる 6 ケースの 


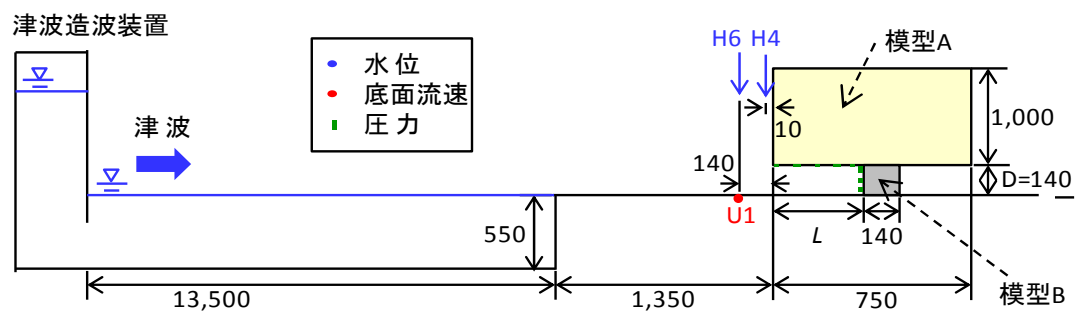

(a) 断面図

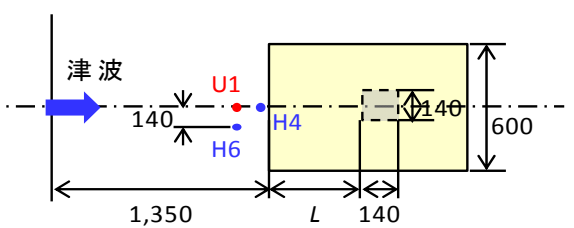

(b) 平面図

図-2＼cjkstart実験セットアップ図（単位 : mm）

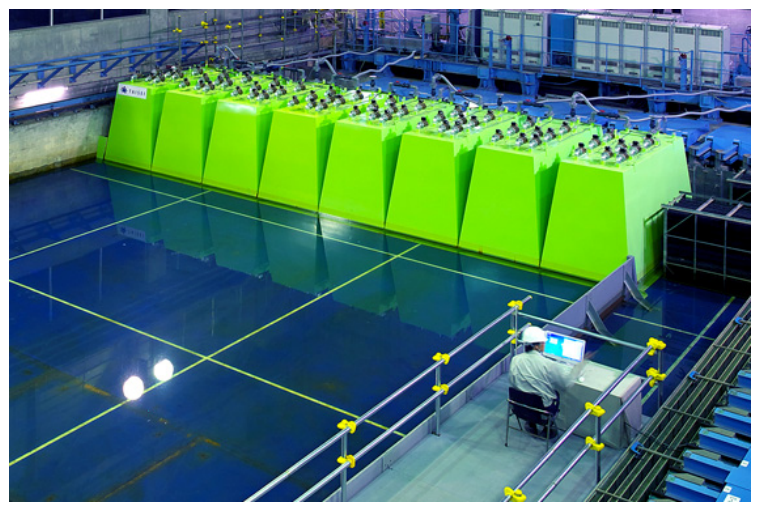

写真-1 津波造波装置

津波（W1〜 W6）を造波した.

想定する実験縮尺は $1 / 50$ とした. 実験のセットアップ 状況を図-2 に示す. 陸域模型として水槽内に高さ $0.55 \mathrm{~m}$ の水平架台を設置し，水平架台の前面は直立護岸を想定 して直立形状とした. 津波造波装置から護岸までの距離 は $13.5 \mathrm{~m}$, 水深は水平架台の高さと同じ $0.55 \mathrm{~m}$ とした. ピロティ構造物模型は, 水平架台の沖側端部から $1.35 \mathrm{~m}$ 陸側に，沿岸方向には造波幅の中央に設置した.

ピロティ構造模型は，2 階以上を対象とした模型(A)と 1 階小規模構造物を想定した模型(B)で構成される. 1 階 高さは $D=0.14 \mathrm{~m}$ とし, 模型(B)の幅および奥行は 1 階高 さと同じ $0.14 \mathrm{~m}$ とした. 模型(B)の配置が津波波力に及 ぼす影響を確認するため, 模型(B)の後退距離 $L$ を 4 ケー 設定した．実験条件を表-1にまとめる.

\section{（2） 計測方法}

計測項目は水位，流速，波圧とし，それぞれの計測機 器を図-2に示寸位置に設置した. 構造物前面の中央に容 量式波高計を, 構造物前面から $0.14 \mathrm{~m}$ 沖側に底面設置型 電磁流速計と容量式波高計を設置した. 津波波圧は小型 圧力計（直径 $10 \mathrm{~mm}$ ) により計測し, 模型(B)の前面中央 の鉛直方向に $31 \mathrm{~mm}$ 間隔で5台の小型圧力計を配置した. これらの小型圧力計で計測した波圧を積分し，模型(B) に作用する津波波力 $F_{b}$ とした. 水位, 流速, 波圧の計測 サンプリング数は, 津波の衝撃的な作用を考慮し, いず れも $1,000 \mathrm{~Hz}$ とした.
表-1 実験条件

\begin{tabular}{c|c}
\hline 津波波形 & $\mathrm{W} 1$ W6 (6 ケース) \\
\hline 模型(B)の後退距離 & $L=0,0.07,0.14,0.28$ m (4 ケース) \\
\hline
\end{tabular}

\section{(3) 津波条件}

通過波として, 構造物模型を設置しない状態でW1 〜 W6 の津波を造波し，浸水深および流速を計測した。構 造物模型前面の $\mathrm{H} 4$ 位置の通過波浸水深 $\eta^{\prime}$ および $\mathrm{H} 6$ 位 置でのフルード数時系列を図-3に示寸，また，各ケース の通過波の諸元を表-2にまとめる.ここで最大通過波浸 水深 $\eta_{0}$ は, $\mathrm{H} 4$ 位置の通過波浸水深 $\eta^{\prime}$ において, 最大波 力に影響を及ぼす第 1 波目の最大浸水深とした. 津波の 水位上昇速度 $w$ は, 最大通過波浸水深 $\eta_{0}$ を津波到達から $\eta_{0}$ に達寸るまでの時間で除して求めたものである. これ を最大通過波浸水深 $\eta_{0}$ および重力加速度 $g$ を用いて無次 元化して整理した. フルード数 Fr は, H6 位置の通過波 浸水深と U1 位置の流速から算出し, H6 位置の浸水深が 最大時の值を示す. 図-3(a)の津波波形および表-2 の無次 元上昇速度から, W1, W2, W4 を立上りが急な津波（以 下，衝撃津波)，W3，W5, W6 を立上りが比較的緩やかな 津波 (以下, 非衝撃津波) に大別し, 以降の検討を行っ た.

\section{3. 実験結果}

\section{（1）小規模構造物に対する津波波力特性}

衝撃津波および非衝撃津波における模型(B)に作用す る津波波圧の鉛直分布を, 模型(B)の後退距離ごとに図-4 に示す. 同図中には, 模型(B)が後退しない $L / D=0$ にお ける模型前面の最大浸水深に対寸る静水圧分布を合わせ て示す. まず, 図-4(b)の非衝撃津波では, 模型(B)の後退 距離によらず，津波波圧の鉛直分布はほぼ同じであり， 模型前面浸水深が最大となった時の静水圧とほぼ等しい ことが分かる. 一方で, 図-4(a)の衝撃津波のうち，L/D $=0$ における津波波圧は, 浸水深最大時の静水圧よりも 小さい. 衝撃津波では, 来襲した津波が模型壁面で衝突 


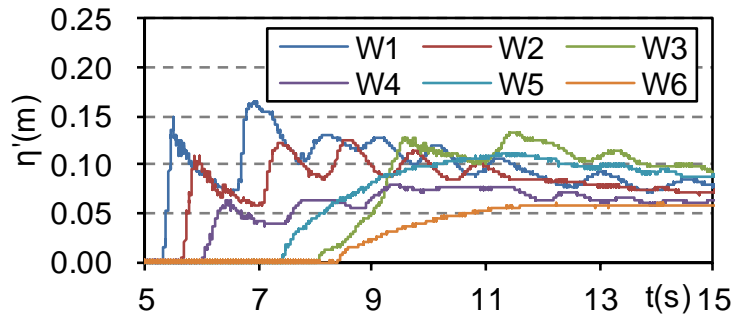

(a) 浸水深 (H4 位置)

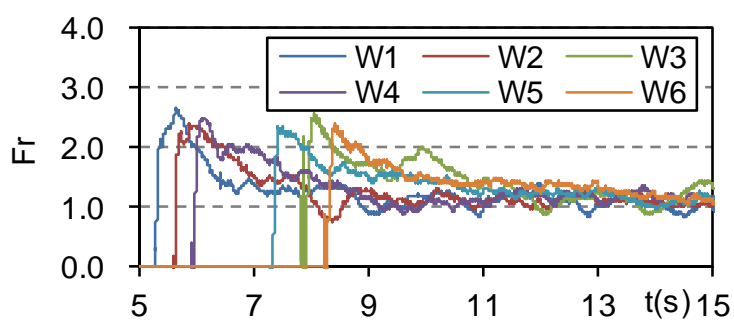

(b) フルード数 (H6 位置)

図-3 入射津波波形（波検定時）

表-2 津波条件

\begin{tabular}{c|c|c|c}
\hline 津波 & $\begin{array}{c}\text { 最大通過波 } \\
\text { 浸水深 } \\
\eta_{0}(\mathrm{~m})\end{array}$ & $\begin{array}{c}\text { 無次元 } \\
\text { 上昇速度 } \\
w / \sqrt{g \eta_{0}}\end{array}$ & $\begin{array}{c}\text { フルード数 } \\
F r\end{array}$ \\
\hline W1 & 0.149 & 0.72 & 2.17 \\
\hline W2 & 0.109 & 0.37 & 2.07 \\
\hline W3 & 0.128 & 0.07 & 1.51 \\
\hline W4 & 0.063 & 0.19 & 1.90 \\
\hline W5 & 0.111 & 0.03 & 1.29 \\
\hline W6 & 0.059 & 0.02 & 1.26 \\
\hline
\end{tabular}

し，上方へ打ち上げられて水位は上昇するが，打ち上げ られた津波水塊は鉛直方向の加速度を持つため, このと きの模型壁面に作用する津波波圧分布は静水圧分布とは 合致しない (Kihara et $a l^{11)}$ )。 また, 模型(B)が 1 階高さ $D$ $=0.14 \mathrm{~m}$ の半分後退した $L / D=0.5$ では，津波波力は全 体的に大きくなり，その鉛直分布は模型(B)の下方より上 方で大きくなっている. その後も，模型(B)が後退するに つれ，津波波圧の鉛直分布は同様の形状のまま，全体的 に波圧が大きくなっている.これは，津波が模型(B)の壁 面に衝突して打ち上がる際，天井によって流体運動が拘 束された結果, 特に天井付近の上方で圧力が上昇したも のと推察される.

次に, 模型(B)の後退距離 $L$ による最大波力 $F_{b \_ \text {max }}$ の変 化を図-5に示す. 同図では, 最大波力 $F_{b-\max }$ を $L=0$ での 最大波力 $F_{b L=0}$ で正規化して示している. 図-4 で示され たように, 非衝撃津波では, 模型(B)の後退距離 $L$ によら ず最大波力 $F_{b \_ \text {max }}$ はほとんど変わらない. 衝撃津波では3

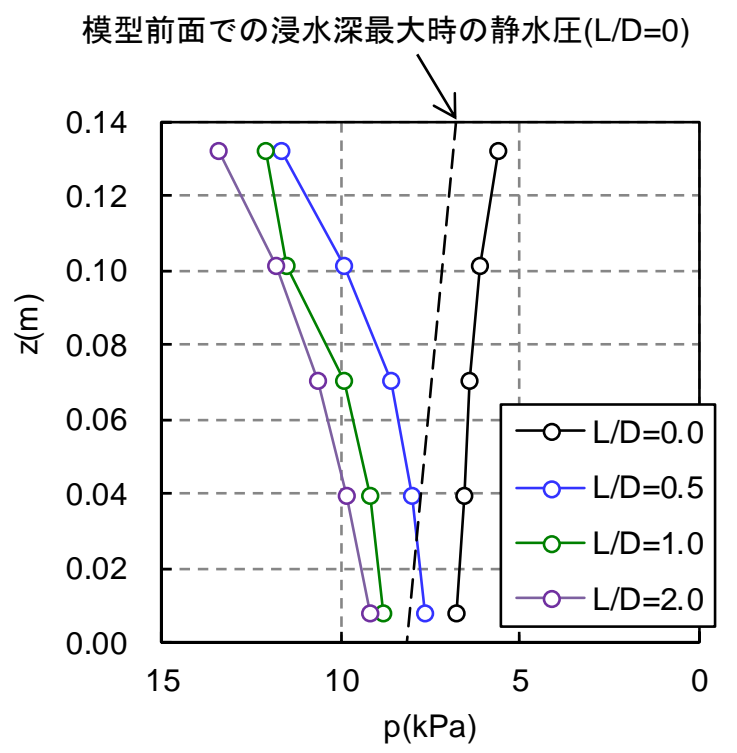

(a) 衝撃津波（津波 : W1)

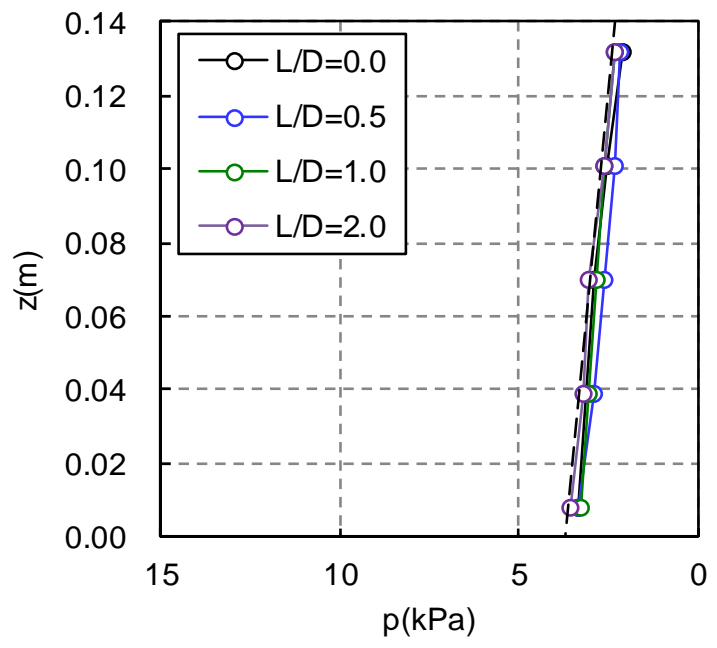

(b) 非衝撃津波（津波 : W3）

図-4 模型(B)に作用する津波波圧の鉛直分布（波力最大時）

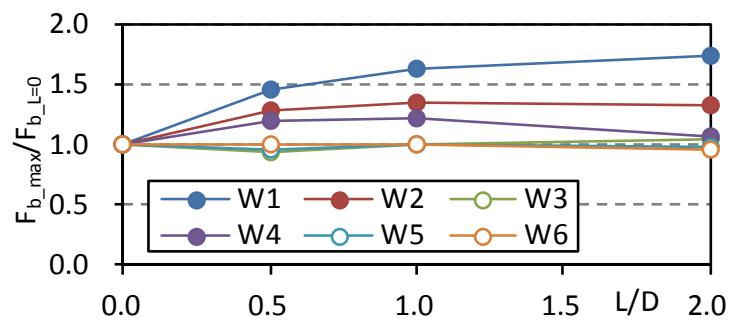

図-5 模型(B)の後退距離による最大波力の変化 $\left(L=0\right.$ での最大波力 $F_{b} L=0$ で正規化 $)$

ケースとも, 模型(B)が $L=0.07 \mathrm{~m}(L / D=0.5)$ 後退したこ とで最大波力 $F_{b \_ \text {max }}$ が 2 5 割増大することが分かる. 模 型(B)がさらに後退すると, 衝撃津波 W1 は増加傾向, 衝 撃津波 W2, W4 は $L / D=0.5$ と同程度以下となっている が, いずれも模型(B)が後退しない $L / D=0$ での波力より 大きな結果が得られている. 
以上より，1 階小規模構造物に作用する津波波力の大 きさや鉛直分布は，津波波形や小規模構造物の後退距離 によって異なることが示された.

\section{（2） フルード数と水深係数の関係}

図-6に示寸底面から高さ $D$ の範囲に作用寸る津波波力 $F_{b}$ を，直立壁を対象とした既往の研究成果（例えば，朝 倉ら $\left.{ }^{12)}\right)$ を参考に, 最大通過波浸水深 $\eta_{0}$ と水深係数 $a$ を 用いて次式で評価する。

$$
F_{b}=\frac{1}{2} \rho g\left(a \eta_{0}\right)^{2}-\frac{1}{2} \rho g\left(\max \left[a \eta_{0}-D, 0\right]\right)^{2}
$$

ここで， $\rho$ は密度， $g$ は重力加速度である. 水深係数 $a$ は 入射津波のフルード数 Fr に関係することが知られてお り, 織田ら ${ }^{13)}$ は理論的アプローチから次の関係式を提案 している. なお，次式は $1 \%$ 以下範囲で $a=1+\sqrt{2} \mathrm{Fr}$ により近似できる.

$$
a=\left(2 F r^{2}+\sqrt{1+8(1+F r)^{2}}-2\right)^{1 / 2}
$$

最大通過波浸水深 $\eta_{0}$ と模型(B)に働く波力 $F_{b}$ の実験結 果を用いて, 式(1)から求めた水深係数 $a$ を図-7 に示す. 模型(B)が後退しない $L / D=0$ では, 津波波形によらず式 (2)に近い值が得られており，直立壁を対象とした既往の 結果と整合している. 一方で, 特にフルード数 Fr の大き な衝撃津波では前節で示したように模型(B)後退時の L / $D>0$ で波力 $F_{b}$ は増大寸るため, 式(2)による水深係数 $a$ を用いて波力を算定すると過小評価となる.

ここで，図-6 に示す $a \eta_{0}$ に，構造物設置時の最大浸水 深 $\eta_{\max }$ の適用を考える. 図-7 には模型(B)が後退しない $L$ $=0$ において模型前面での最大浸水深 $\eta_{\text {max }}$ と最大通過波 浸水深 $\eta_{0}$ の比を×で示した. $\eta_{\max } / \eta_{0}$ は，フルード数 Fr の小さな非衝撃津波は式(2)および実験結果から求めた 水深係数 $a$ と同程度であるが, フルード数 Fr の大きな衝 撃津波は式(2)より大きくなる。これは，図-4(a)で示した ように，衝撃津波の津波波圧分布が模型前面での最大浸 水深 $\eta_{\text {max }}$ の静水圧分布とはならないことに起因する.こ の様な場合には，水深係数 $a$ に $\eta_{\max } / \eta_{0}$ を用いると，津波 波力を大きく過大評価する場合があることに注意が必要 である。

\section{4. 津波波力評価式の提案}

\section{（1） 小規模構造物が後退しない場合}

模型(B)が後退しない $L=0$ のケースについて，模型前

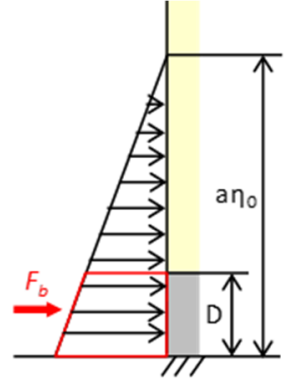

図-6＼cjkstart式(1)の記号説明図

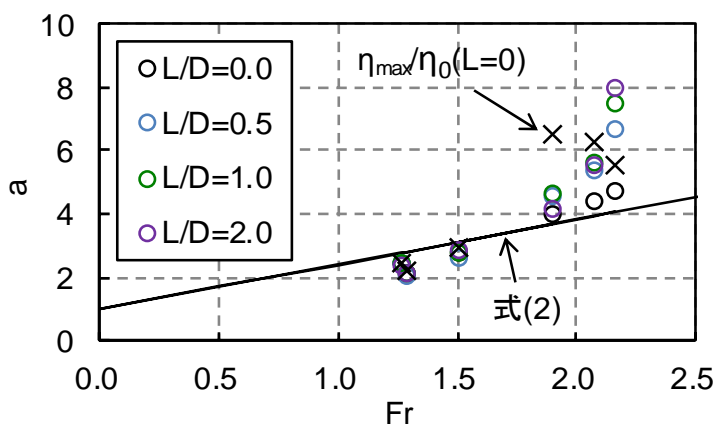

図-7フルード数と水深係数の関係

面浸水深 $\eta$ と津波波力 $F_{b}$ の経時変化を図-8 に示す。図 -8(b)に示す非衝撃津波では模型前面浸水深 $\eta$ と模型(B) に作用する津波波力 $F_{b}$ の最大值はほぼ同時刻に現れて

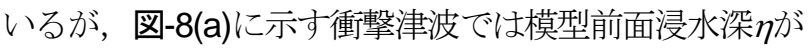
最大になる前に波力 $F_{b}$ のピークが現れており，津波波形 によって津波波力の経時特性が異なることが分かる．通 過波検定時の通過波浸水深 $\eta^{\prime}$ を用いて，各時刻で式(2) による水深係数 $a$ から求めた $a \eta^{\prime}$ および式(1)から推定し た津波波力 $F_{b}$ を図-8 中の青線で示す. 同図より模型(B) が後退しない場合は，津波波形によらず，入射津波のフ ルード数 Fr と浸水深時系列 $\eta^{\prime}$ から式(1), (2)を用いて津 波波力 $F_{b}$ の経時変化をおおむね推定できることが分か った.

水深係数 $a$ を式(2)で求め, 式(1)により算出した模型(B) に作用する最大波力と，実験結果の比較を図-9 に示す. 同図には, 水深係数 $a$ に模型前面浸水深の最大值 $\eta_{\max }$ と 最大通過波浸水深 $\eta_{0}$ の比を用いた結果も示している. 水 深係数 $a$ を式(2)から求めて算出した津波波力は，実験結 果を良く再現していることが確認できる，一方，図-7で 示したように, 水深係数 $a$ に $\eta_{\max } / \eta_{0}$ を用いると, 衝撃津 波のケースで津波波力を過大に算出する結果となった.

\section{（2）小規模構造物が後退する場合}

模型(B)が後退する場合は, 特に衝撃津波で最大波力が 増大寸る傾向となった（図-5 参照)。これは，津波が模 型(B)の壁面に衝突して打ち上がる際, 天井によって流体 運動が拘束されることが原因と考えられる，そこで，模 


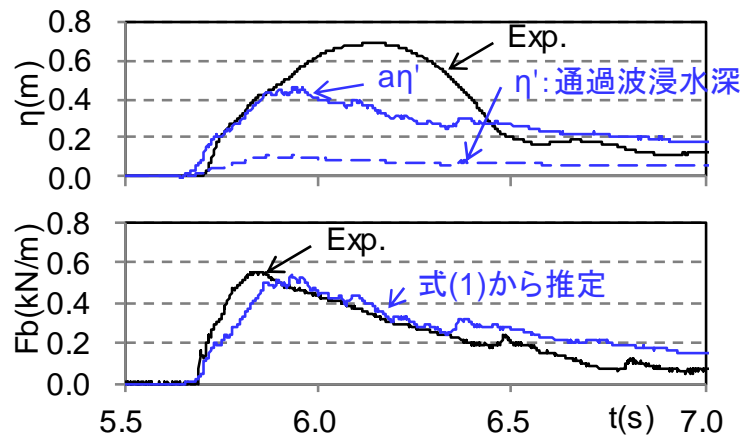

(a) 衝撃津波（津波 : W2）

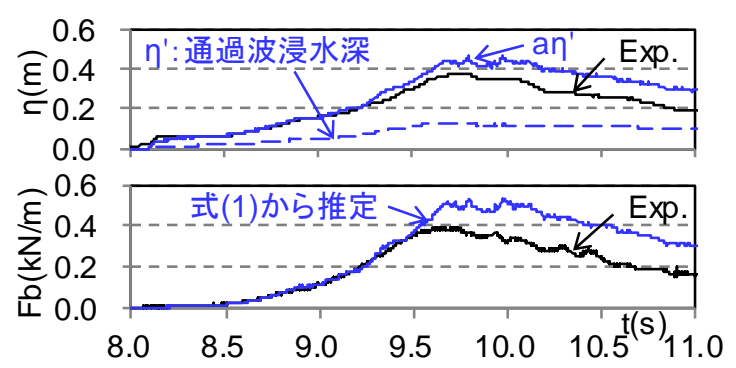

(b) 非衝撃津波（津波 : W3）

図-8 模型前面浸水深 $\eta$ おび津波波力 $F_{b}$ の経時特性 $(L=0)$

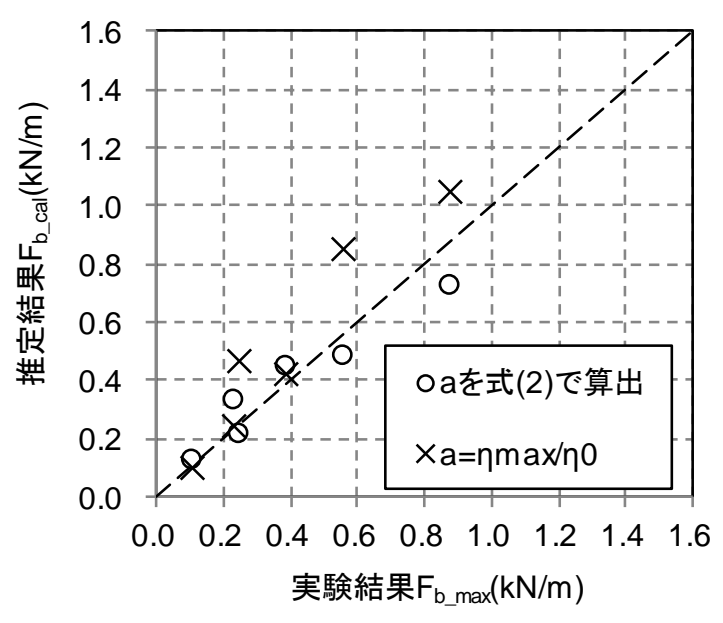

図-9 最大波力の推定結果と実験結果の比較 （模型(B)が後退しない場合， $L=0$ )

型(B)後退時の波力 $F_{b}$ は, ピロティ構造 1 階部に流入す る入射津波の運動量に一致すると仮定し, 次式により推 定した.

$$
\begin{gathered}
F_{b}=\left\{\frac{1}{2} \rho g \eta_{0}{ }^{2}-\frac{1}{2} \rho g\left(\max \left[\eta_{0}-D, 0\right]\right)^{2}\right\} \\
+\rho\left(\min \left[\eta_{0}, D\right]\right) v^{2}
\end{gathered}
$$

ここで， $\eta_{0}$ は最大通過波浸水深， $v$ は通過波において $\eta_{0}$ が出現した時の流速である. ここでは，最大通過波浸水

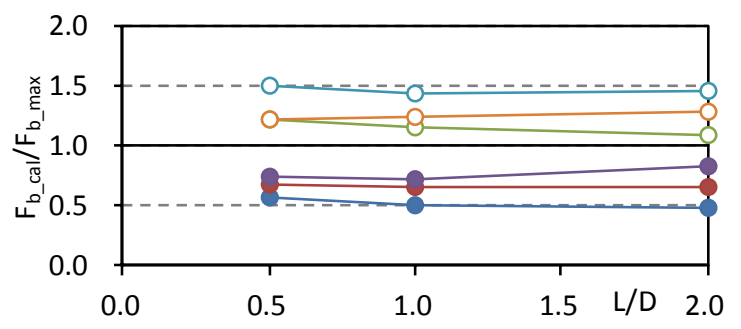

(a) 式(1)による算定結果

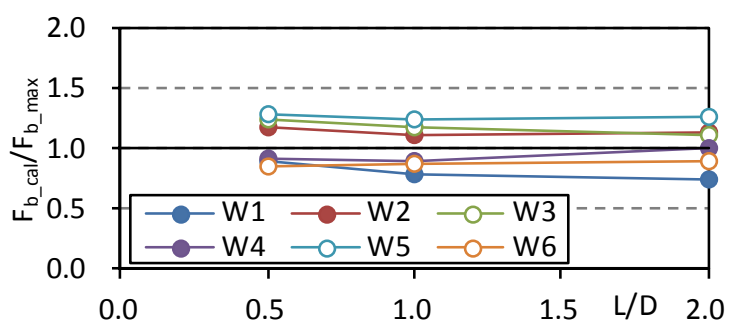

(b) 式(3)による算定結果

図-10 最大波力の推定結果の比較

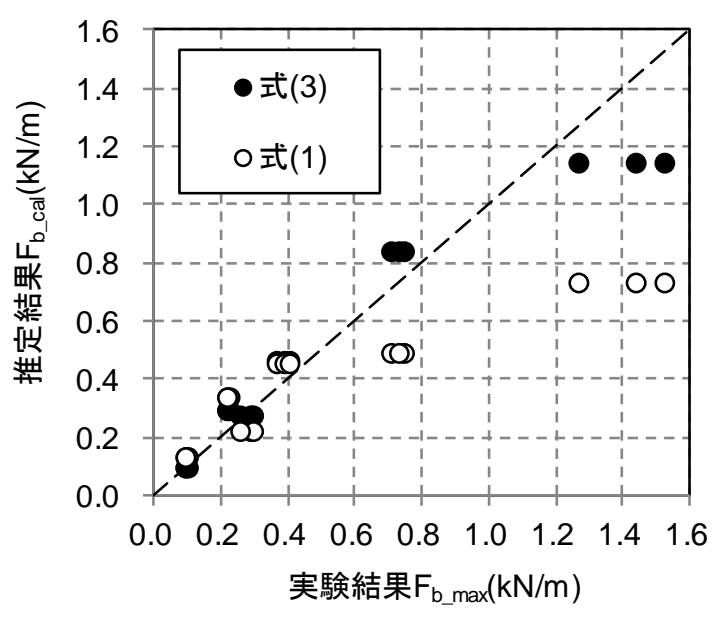

図-11 最大波力の推定結果と実験結果の比較 (模型(B)が後退する場合， $L>0$ )

深 $\eta_{0}$ と流速 $v$ に，岸沖位置が同じ H6, U1（図-2 参照）の 計測值を使用した.

模型(B)後退時の最大波力について, 式(1)および式(3) により推定した結果を図-10に示す. 図-10(a)の水深係数 $a$ を用いた式(1)による算定結果は実験結果の 0.5～1.5 倍 の範囲となっているが，図-10(b)の入射津波の運動量に より算出した式(3)による結果では推定精度が向上し, 実 験結果の $0.7 〜 1.3$ 倍の範囲に収まっている. 最大波力の 推定結果と実験結果の比較を図-11 に示す. 水深係数 $a$ を用いた式(1)に比へ，入射津波の運動量を用いた式(3) により，特に衝撃津波のケースで推定精度が大きく向上 することが分かる，ただし， $F_{b \_ \text {max }}$ が $1 \mathrm{kN} / \mathrm{m}$ を越える衝 撃津波W1 では, まだ10〜25\%の過小評価となっている. $\mathrm{W} 1$ では最大通過波浸水深 $\eta_{0}$ が 1 階高さ $0.14 \mathrm{~m}$ を越えて 
おり (表-2 参照), 式(3)で 1 階高さ以上の運動量を無視 しているが，オリフィスと類似の効果により，式(3)で評 価したよりも大きな運動量が模型(B)に作用した可能性 が考えられる.これについては, 今後の検討課題である.

\section{5. まとめ}

ピロティ構造の 1 階小規模構造物を対象に実施した津 波波力実験より，津波波形によらず，直立壁の場合と同 様に入射津波のフルード数と浸水深時系列を用いて波力 の経時評価が可能であることが示された。また，1階部 材が後退し，衝突した津波の流体運動が天井によって拘 束される場合の津波波力は，入射津波の運動量を用いて 推定可能であることが示された.

\section{参考文献}

1) 津波避難ビル等に係るガイドライン検討会（内閣 府）：津波避難ビル等に係るガイドライン（巻末資料 (2)), 2005.

2) 国土交通省 国土技術政策総合研究所: 津波避難ビル 等の構造上の要件の解説, 国総研資料,第 673 号, 2012.

3）青木悟，水谷法美，平川信也，芦澤哲 : 建物ビルに作 用する津波力に及ぼす建物形状および津波作用方向 の影響に関する研究, 土木学会論文集 B2 (海岸工学), Vol.70, No.2, pp.I_811-I_815, 2014.

4) 末長清也, 岩前伸幸, 池谷毅, 秋山義信, 舘野公一, 鈴木紀雄 : 多柱構造物に作用する津波波力に関する実 験的研究，土木学会論文集 B3 (海洋開発)，Vol.70, No.2，pp.I_390-I_395， 2014.

5) 松冨英夫，決得元基，嶋津朋，長沼駿介，桜井亮 : 開 口部を有する RC 造建物における津波の水平力と鉛直
力の低減，土木学会論文集 B2 (海岸工学), Vol.70, No.2, pp.I_371-I_375, 2014.

6) 決得元基, 松富英夫, 藤井俊典, 富井達也 : RC 造建 築物に作用する津波鉛直力とその低減法，土木学会論 文集 B2 (海岸工学), Vol.71, No.2, pp.I_367-I_372, 2015.

7) 岩田善裕，壁谷澤寿一，奥田泰雄，秋山義信，福山貴 子，鈴木一輝，池谷毅：大きな開口を有する建築物に 作用する津波力に関する実験的研究 その 1〜その 4 日本建築学会大会学術講演梗概集, pp.57-64, 2016.

8) 岩前伸幸, 秋山義信, 池谷毅，鈴木紀雄，舘野公一： 開口を有する建築物に作用する津波荷重, 土木学会論 文集 B2（海岸工学），Vol.72，No.1，pp.51-61， 2016.

9) 本田隆英, 織田幸伸, 伊藤一教, 渡辺征晃, 高畠知行 : ピロティ構造を対象とした津波波力に関する実験的 研究，土木学会論文集 B3 (海洋開発)，Vol.70，No.2, pp.I_456-I_461， 2014.

10）本田隆英，小俣哲平，織田幸伸，伊藤一教：ピロティ 構造の部材に働く津波波力に関する実験的研究，土木 学会論文集 B2 (海岸工学), Vol.72, No.2, pp.I_979-I_984, 2016.

11) Kihara, N., Niida, Y., Takabatake, D., Kaida, H., Shibayama, A. and Miyagawa, Y. : Large-scale experiments on tsunami-induced pressure on a vertical tide wall, Coastal Eng., Vol.99, pp.46-63, 2015.

12）朝倉良介，岩瀬浩二，池谷毅，高尾誠，金戸俊道，藤 井直樹，大森政則 : 護岸を越流した津波による波力に 関する実験的研究, 海岸工学論文集, Vol.47, pp.911-915, 2000.

13）織田幸伸，本田隆英，高畠知行：陸上構造物に働く津 波波力の時系列評価に関する研究，土木学会論文集 B2 (海岸工学), Vol.70, No.2, pp.I_796-I_800, 2014.

(2017.2.2 受付)

\section{A STUDY ON CHARACTERISTICS OF THE TSUNAMI FORCE ACTING ON MEMBERS OF PILOTI-TYPE STRUCTURES}

\section{Takahide HONDA, Teppei OMATA, Yukinobu ODA and Kazunori ITO}

It is known that piloti-type structures, which have open space on the ground floor, have an advantage for tsunami hitting because tsunami can pass through the ground floor. There is a basic guideline for the design of piloti-type structures for tsunami forces but detailed information such as tsunami forces acting on the elevator hall or the ceiling is not speculated. It was also reported that tsunami forces acting on members of piloti-type structures such as the elevator hall or the ceiling estimated by the existing guideline were occasionally much smaller than the tsunami forces measured by the hydraulic physical model tests.

In the present study, hydraulic physical model tests were performed by using the tsunami wave generator in the wave basin in order to investigate the characteristics of tsunami force acting on the elevator hall of the piloti-type structures. As a result of the physical model tests, the tsunami forces acting on members of the structure could be estimated by the Froude Number of the incoming tsunami, same manner as in the case of a vertical wall. When the elevator hall of the piloti-type structures is located in the landward side, the tsunami forces acting on the elevator hall becomes larger because the tsunami flow is restricted at the ceiling in front of the elevator hall. This tsunami forces could be estimated by the momentum of the incoming tsunami. 